\title{
How does CEO Compensation in U.S Corporations Compare with European and British Firms? A Review of the Literature
}

\author{
Brian Maruffi ${ }^{1}$, Augustine C. Arize ${ }^{2}$, Manar Awad ${ }^{3}$, John Malindretos $^{4} \&$ Alfred Verrrios $^{4}$ \\ ${ }^{1}$ Gabelli Graduate School of Business, Fordham University, USA \\ ${ }^{2}$ Department of Economics and Finance, College of Business, Texas A\&M, USA \\ ${ }^{3}$ Cotsakos College of Business, William Paterson University, USA \\ ${ }^{4}$ Department of Economics and Finance, Cotsakos College of Business, William Paterson University, USA \\ Correspondence: John Malindretos, Department of Economics and Finance, Cotsakos College of Business, William \\ Paterson University, USA. E-mail: jnmalindre@optonline.net
}

Received: June 2, 2015

Accepted: June 30, 2015

Online Published: August 17, 2015

doi:10.5430/afr.v4n3p114

URL: http://dx.doi.org/10.5430/afr.v4n3p114

\begin{abstract}
During the past 10 years, it has been speculated that the international differences or "pay gap" between the compensation of chief executive officers (CEOs) in the U.S. and that of their foreign counterparts has significantly decreased. The growing similarity has been a result of widespread internationalization (international diversity of the board and foreign institutional ownership, investor demand, and sales) and Americanization of non-U.S. firms (directors with U.S. board experience and U.S. institutional ownership, cross-listings, and acquisitions) (Fernandes et al., 2012, p.348). This paper will examine the growing similarity in CEO compensation across countries. Various determinants of CEO compensation will be examined, including: governmental regulations, shareholder interest in light of the board of directors and an executive's institutional ownership, stock options, the size of a firm in light of sales revenue and profit and the number of employees in a firm, and bonus plans. The research will look at the parallel in compensation of CEOs in the U.S. with those in the UK, Germany, and Japan and its adaptation throughout the years.
\end{abstract}

Keywords: CEO, Compensation, U.S., Firms

\section{Introduction}

There are many studies of CEO compensation that clearly indicate that CEO pay and other forms of compensation have increased significantly and dramatically over the past three decades as compared with the average compensation of production workers. This trend is shown in Figure 1:

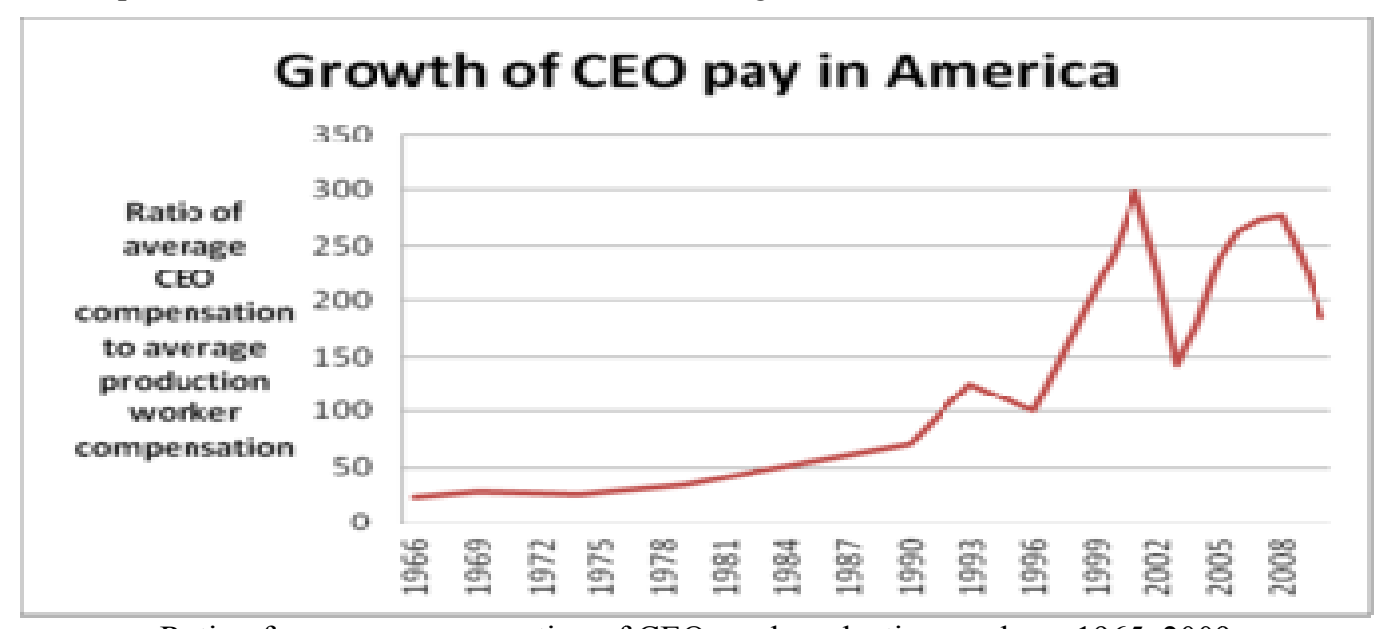

Ratio of average compensation of CEOs and production workers, 1965-2009

Source: Economic Policy Institute. 2011. Based on data from Wall Street Journal/Mercer, Hay Group 2010 


\section{Levels of CEO compensation in the U.S.}

In studies conducted before the turn of the twenty-first century, when analyzing CEO pay in the U.S. versus abroad, the same conclusion would be reached that the CEOs of U.S. Corporations are paid significantly more than any other executive across developed countries. Research studies have concluded that "CEOs in the United Sates are paid significantly more than the CEOs of foreign corporations (e.g., Abowd and Bognanno (1995), Abowd and Kaplan (1999), and Murphy (1999)" (Murphy, 2012, p.118). Despite increases in CEO compensation in UK and other countries in the late 1990s, it appeared that there was still a significant pay gap between U.S. CEO and foreign CEO Compensation. The compensation of CEOs in U.S. firms increased rapidly over the decade. For example a survey of CEO Compensation conducted in 1997, found that pay levels for CEO's of U.S. Corporations rose $18 \%$ in that year alone. This trend in international compensation was expected to continue increase over the next two decades. For example, in 1997, CEOs of the largest 500 U.S. Corporations were paid ten times more than the CEOs of the largest 500 companies in the U.K. (Conyon \& Murphy, 2000, p.640). When comparing the average total compensation of U.S. executives (from a sample of 1,666 CEOs) to UK executives, U.S. CEOs were paid $500 \%$ more than their British counterparts (Conyon \& Murphy, 2000, p.646). When controlling for industry, firm size, and other characteristics, Conyon and Murphy (2000) found that U.S. CEOs earned about 200\% more than UK CEOs. The disparity in pay is also presented in comparing salaries of top executives in Germany to those in the U.S. In 1997, the highest executive salary in Germany was for the CEO of BMW at 3.5 million DM, compared to a staggering 181 million DM salary of the HealthSouth CEO in the U.S. (Elston \& Goldberg, 2001, p.3). In comparison to Japan, a CEO of a mid-sized firm in the US was paid over $\$ 300,000$ more than a Japanese CEO of a mid-sized firm (Murphy, p.17) Since the 1990s, CEO compensation in the US has outpaced corporate profits, economic growth and the average compensation of all workers. Between 1980 and 2004, Mutual Fund founder John Bogle estimates total CEO compensation grew 8.5 percent/year compared, compared to corporate profit growth of 2.9 percent/year and per capita income growth of 3.1 percent. ${ }^{\text {By }} 2006$ CEOs made 400 times more than average workers - a gap 20 times bigger than it was in 1965. As a general rule, the larger the corporation the larger the CEO compensation package. The share of corporate income devoted to compensating the five highest paid executives of (each) public firms more than doubled from 4.8 percent in 1993-1995 to 10.3 percent in 2001-2003. The pay for the five top-earning executives at each of the largest 1500 American companies for the ten years from 1994-2004 is estimated at approximately $\$ 500$ billion in 2005 dollars. A study by the executive compensation analysis firm Equilar Inc. for the New York Times found that the median pay package for the top 200 chief executives at public companies with at least $\$ 1$ billion in revenue in 2012 was \$15.1 million - an increase of 16 percent from 2011.

However the critical focus of this paper is not on the pay inequities or disparity between CEO and U.S. worker compensation. Rather, our objective is to review current trends and research to determine whether the rise in CEO compensation in the U.S, is aligned with the compensation of CEO's in other countries (e.g. UK, Germany, Japan, etc...). In recent years, the gap between CEO pay in the U.S. versus abroad has been decreasing. This is evident by looking at the shift in CEO pay premium. Defined by Fernandes, Ferreira, Matos, and Murphy (2012) as the amount of riskless cash compensation that would make a CEO indifferent between holding an undiversified and an unconstrained portfolio. In 1997, the average U.S. CEO of a financial firm earned 580\% more than their UK CEO counterparts (Conyon \& Murphy, 2000, p.646). By 2006, the U.S. pay premium was found to be "economically modest," with U.S. CEOs earning $26 \%$ on average than their foreign counterparts (Fernandes et al., 2012, p.324). In 2011, Conyon, Core, and Guay found that U.S. CEO pay premiums compared to that of UK CEOs have become marginal since 2003 and became statistically insignificant by 2007 (Murphy, 2012, p.120). Historically, the U.S. pay premium declined from $58 \%$ in 2003 to $2 \%$ in 2007, and rose back to only $14 \%$ in 2008, as shown in Figure 1 below. (Fernandes et al., 2012, p.326). There is increasing evidence that indicates that today, there is no significant difference in the compensation of U.S. CEO's as compared with their counterparts in the UK, Germany and Japan. 


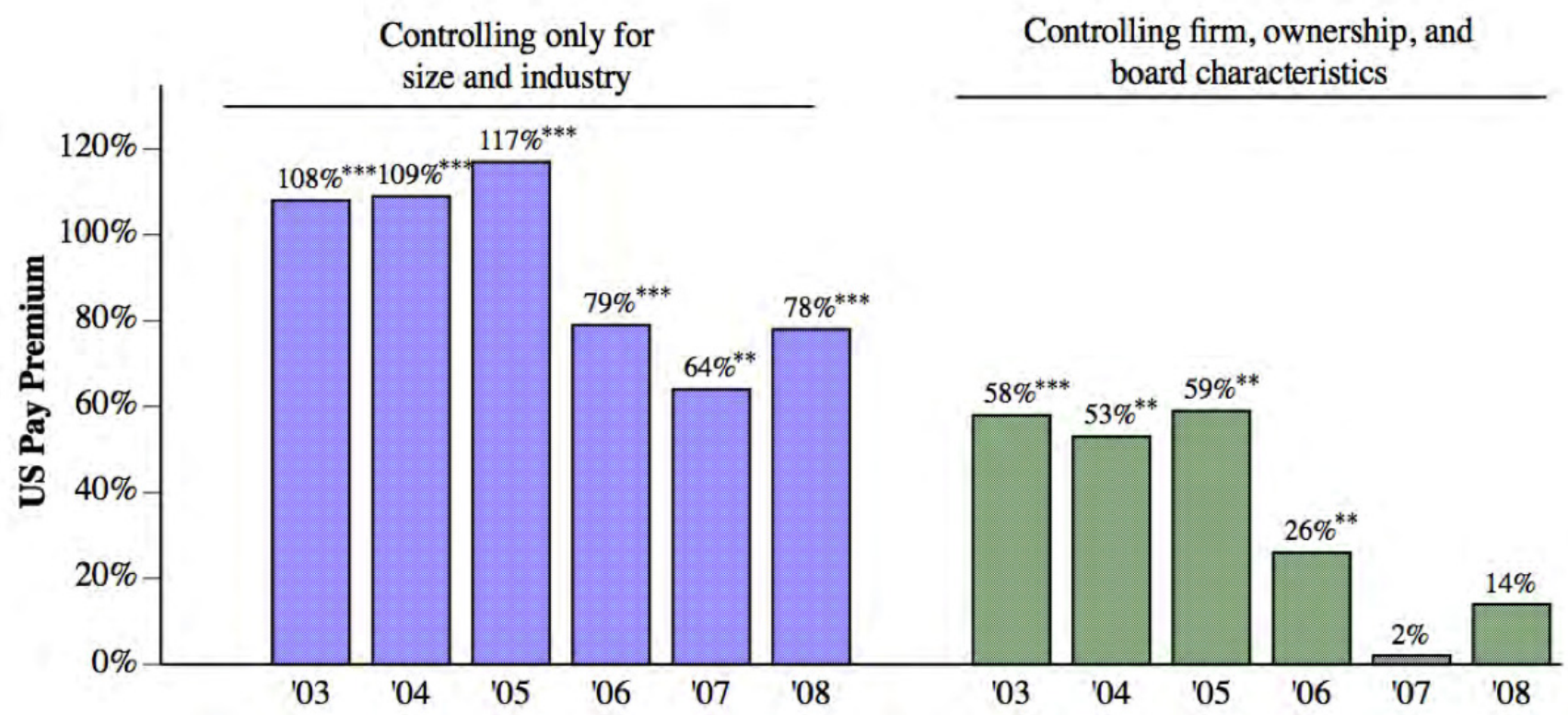

Figure 1. The Evolving (and Disappearing) U.S. Pay Premium. Obtained from Murphy, Kevin J., 2012, Executive Compensation: Where We Are, and How We Got There. Handbook of the Economics of Finance No. FBE 07.12, $1-175$.

\section{The Effects of Government Regulation}

Since the turn of the twenty-first century, the U.S. government has become a driving force in constraining executive pay and in mediating CEO compensation. Recent research indicates that political factors have played a major role in the diminishment of executive pay in the U.S., making government regulations a critical determinant of CEO pay that cannot be ignored (Murphy, 2012, p.42). The adaptation of new government regulations, in terms of accounting reforms, and increased shareholder pressure changed the structure of CEO compensation. Accounting principles, such as the Sarbanes-Oxley Act of 2002, was enacted in response to large corporate scandals that had high economic costs and devastating effects on financial markets. Such acts mainly aim to prevent corporate fraud and shift executive focus to align with that of shareholder interest.

However, it also places restrictions on executive compensation. Such as forcing CEOs to, "return all profits gained from selling stock or annual bonuses should this pay come within twelve months of a company reporting inaccurate accounting statement" (Kuehn, 2013, p.24). The threat of government regulation alone has resulted in decreasing or constraining the growth of their executive's compensation.

As a result of the financial crisis of 2007, the growth of executive compensation came under greater scrutiny by politicians and the media and became the subject of public outrage (Kuehn, 2013, p.1). The government's direct and indirect intervention into CEO pay increased, and executive compensation declined during the Great Recession of 2008-2009 (Murphy, 2012, p.1). Government intervention continued to focus on and include accounting rules, tax policies, listing requirements, and others. Despite government efforts, they often did not align with the profit-making interests of executive's and directors' and shareholders. Regulations enacted by politicians aimed solely at limiting executive pay in response to media coverage and public outrage. This represented a disregard and misunderstanding of the views and concerns of shareholders which is not to simply focused on reducing CEO pay packages, but more importantly, providing executives with incentives and rewards for maximizing the firm's value (Kuehn, 2013, p.8). Business analyst concluded that political pressures on increasing disclosure requirements resulted in reducing the relationship between executive compensation and firm performance by decreasing executive pay and providing disincentives for CEOs to improve the ROI and performance of the firm (Murphy, p.23-24).

In the UK, executive compensation has also affected by government regulations. Stricter government intervention began after the UK Confederation of Business and Industry, the UK's top business lobbying organization, published the Greenbury Report in 1995. The report greatly impacted the pay packages of UK CEOs. There was a growing necessity for the report after plan options of executives came under scrutiny when the CEO of a private utility company's exercised options worth millions of pounds (Murphy, p.10). The report recommended instituting some restrictions including a cap placed on the amount of options a CEO can be awarded and that the, "remuneration 
committee should consist exclusively of non-executive directors who have no involvement in the company's day to day operations" (Murphy, p.11).

Disclosure requirements affect different countries differently. In Germany, a bill passed in 2005 the German Federal Government requiring companies to publicly disclose individual pay packages of their key executives (Schmidt, 2012, p.3). In analyzing 122 managers in 22 firms, Schmidt (2012) found that this disclosure reform actually lead to an increase in executive compensation. Previously uninformed executives about the scale of their peer's pay now came under social pressure to increase their own. Ang, Nagel, and Yang (20120) found a correlation between an increase in CEO compensation and an increase in the number of local CEO peers.

\section{Internationalization and Americanization of Non-U.S. Firms}

The growing shift in CEO compensation between US and abroad is a cause, in part, of internationalization. The, "higher risk (and rewards) associated with international firm $\{\mathrm{s}\}$ can also be expected to impact CEO compensation levels" (Oxelheim and Randov, 2004, p.3). CEOs of internationalized firms are exposed to a plethora of risks they would otherwise not encounter in a local or domestically diversified firm. They have to account for external variables and occurrences that are beyond their control. CEOs would expect to receive a greater risk premium for managing these extra risk factors (Oxelheim and Randov, 2004, p.5).

The difference between CEO compensation of U.S. and non-U.S. firms, those with a high portion of sales in foreign markets and internationally diversified boards, has become virtually insignificant (Fernandes et al., 2012, p.325). Exposure of non-U.S. firms to international markets has an effect on CEO compensation. In specific, exposure to capital markets (international-cross listing), the market for corporate control (foreign board membership), and the product and labor markets (export and foreign sales). Influence from capital markets and the market for corporate control enhances CEO compensation and directly strengthens a firm's financial performance in the product and service market (Oxelheim and Randov, 2004, p.3). Internationalization of a firm positively correlated with CEO pay. Internationalization entails firms with foreign institutional ownership, membership in MSCI index, have a fraction of foreign sales, and have internationally diversified board members (Fernandes et al., 2012, p.349).

When looking at actions of non-U.S. firms, a discrepancy has been found when comparing activities that involve U.S. companies and those that don't. For example, Gerakos, Piotroski, and Srinivasan (2011) found that CEOs of UK firms with U.S. operations experienced higher levels of equity-based compensation and bonuses as opposed to UK firms with non-U.S. foreign operations (Gerakos et al., 2011, p.21). CEO pay was found to be positively and significantly correlated (GIVE CORR) with Americanization of non-U.S. firms. Specifically, entailing firms with U.S. institutional ownership, cross-listing on U.S. exchanges (proxy for U.S. investor demand), acquisition of U.S. firms (proxy for to exposure to U.S. product and labor markets), and having board of directors who also sit on boards of U.S. firms (proxy for exposure to U.S. pay practices). Specifically it was reported that a $10 \%$ increase in U.S. institutional ownership of a firm led to about a $16 \%$ increase in CEO pay. Also, non-U.S. companies acquiring U.S. firms paralleled an increased in CEO compensation (Fernandes et al., 2012, p.350-351). UK firms involved in a U.S. acquisition increased both total CEO compensation and incentive-based pay, but the same could not be found in the acquisition of non-U.S. firms (Gerakos et al., 2011, p.4). Similarly, UK firms listed on U.S. stock exchanges paid their CEOs higher salaries and cash compensation, than those not listed on such exchanges. Foreign firms cross-listed on U.S. exchanges had a $21 \%$ increase in CEO pay. Non-U.S. firms with board members also on boards of U.S. firms offered larger cash compensation to their executives than firms with non-U.S. foreign board of directors (Gerakos et al., 2011, p.22).

With the increased internationalization and Americanization of non-U.S. firms, there are incentives for Americanized firms to adopt U.S. pay practices. The U.S. compensation packages are significantly more lucrative and attractive to foreign CEOs. They include a higher level of expected total compensation, as well as larger grants of stock and options (Fernandes et al., 2012, p.352). A reason for adoption the compensation packages of U.S. parent companies may include a need to eliminate pay disparities that arise from business done with U.S. firms such as U.S. mergers and acquisitions of U.S. operations (Gerakos et al., 2011, p.1). Another important reason for adopting more competitive U.S, compensation practices is be more successful at recruiting, attracting and retaining talent in the global managerial labor market (Fernandes et al., 2012, p.352). It is not uncommon for one to be paid based on their talent. Therefore, in theory, CEOs who have successfully increased firm performance and stock value will need to be paid accordingly by their firms in order to retain their services (Murphy, p.24). However, a recent analysis of compensation data publicly released by Equilar (Chemi, E., and Giorgi 2014) shows little correlation between CEO pay and company performance. Equilar ranked the salaries of 200 highly paid CEOs. When compared to metrics such as revenue, profitability, and stock return, the scattering of data looks pretty random, as though performance doesn't 
matter. The comparison makes it look as if there is zero relationship between pay and performance. The ranking of the 200 CEOs Equilar looked at to their company's stock returns. They found that a CEO's income ranking is only based on $1 \%$ of the company's stock return. That means that 99 percent of the ranking has nothing to do with performance at all. (The size and profitability of companies didn't affect the random patterns.)

\section{Shareholders Interest}

\subsection{The Board of Directors}

The board of directors plays a significant role in determining the CEO compensation. The Board determines how much the executive should be paid, but also what factors should be used to evaluate their compensation (Murphy, p.23). The members of the board play a critical role in deciding to act in the best interest of the CEO rather than their corporation. There have been attempts to restrict the CEOs influence over his/her board, most effectively, by ensuring that a board is composed of many independent outside directors. Buigut, Soi, and Koskei (2014) found that the percentage of independent directors serving on a firm's board was significantly related to a decrease in CEO compensation levels (Buigit et al., 2014, p.223). Chhaochharia and Grin-stein (2009) found similar results to be true in the U.S. A diversified board structure of independent directors can also be essential, in Germany, having representation from banks, in specific, was found to negatively impact CEO compensation (Elston \& Goldberg, 2001, p.4). Such independent directors are meant to reduce agency problems, which are conflicts of interest between company management and shareholders, and align a CEO's interest with that of shareholders. The Board has the power to enforce this by threatening executives with less pay or termination if they do not act in favor of shareholder value, or implementing incentive contracts link CEO compensation with profitability and shareholder value (Murphy, 2012, p.132). This increases the probability that the CEO will make greater efforts towards increasing shareholder value.

However, outside directors are often less concerned about determining CEO compensation when they receive little or no benefit from overseeing executive compensation and use shareholder money to pay the CEO rather than their own (Murphy, 2012, p.132). Zajac and Westphal (1995) suggested that independent outside directors should own stock in the firm's that they serve. By giving Board Members some "skin in the game" they will think more like owners and therefore their interests will be more closely with shareholder interests. This increases the probability that Board members will fulfill their fiduciary responsibilities related to the determination of CEO compensation packages. It is presumed that when serving board members become institutional investors, they will place more emphasis on firm performance and a desire to increase shareholder value (Murphy, p.23). This principle has had a significant impact on board structures. For example, in Germany, there is a 2-tiered board system or a management and supervisory board serving as one unit, where independent directors with large block stock ownership can have a negative effect on CEO compensation (Elston \& Goldberg, 2001, p.4).

Unfortunately, in utilizing independent directors, social capital becomes a problem. It has been found that the increased similarity between a CEO and their chair, leads to an increased compensation for the CEO (Murphy, p.18). The issue of interlocking directorship or "mutual back scratching" arises, in which CEOs serve as board members in each other's corporations (Murphy, p.19; Posner, 2009, p.1024).

Despite having no say in the board, CEOs can still influence the determination of their own pay structure and size. In the UK, individuals of a company's management team often serve as nonexecutive board members of their own company. These individuals were most likely hired and promoted by their CEO, making them extremely vulnerable to influence when setting their CEOs pay packages (Murphy, p.20). These strong connections between CEOs and their directors are a reason for increased compensation of U.S. CEOs as oppose to their foreign counterparts.

The board of directors can have a major impact on firm performance. When Boards play a key role in determining CEO compensation, they can act in favor of the shareholder and place greater emphasis on revenue generation. On the other hand, the board can reward a CEO a large compensation package that is not based on the CEO's performance (Buigit et al., 2014, p.223). The second scenario is more likely to occur if a CEO also serves as chairman of the board, called duality, which was found to be a much more significant issue for U.S. firms when compared to British companies. When CEO and Chairman positions are held by the same person, they have been found to have a greater influence on board decisions and therefore were much more likely to have higher salaries (Murphy, p.19). However, this trend has shifted, as Bizkaj and Anderson (2003) found that CEOs sitting on their own boards earned less than other CEOs. These CEOs were usually founders of the company or their family members and were more concerned with influencing the pay level and structure of their subordinates. Elston and Goldberg (2001) found that executives of German firms, as with executives of U.S. firms, have lower levels of 
compensation as their ownership concentration increases. No matter the structure or members of the corporate board, they are a prominent factor in determining CEO compensation and shaping corporate strategy.

\subsection{Executive Institutional Ownership}

CEO compensation is a crucial part of corporate governance. Giving executives incentives, or lack of, to act in the most beneficial interest of company shareholders; greatly impacting the compensation of other employees and investors (Murphy, p.1). As with independent directors, the greater a CEO's institutional ownership in the firm they serve, the more their interest will align with that of their shareholders. An executive's ownership in a firm will motivate them to work towards increasing firm value. The scale of an executives pay will not be the defining factor in gearing performance, as CEOs will now act to increase firm value for their own best interest (Fernandes et al., 2012, p.325).

Through a CEOs holdings in the firm, their wealth becomes directly related to that of shareholders. Whether that be holdings of shares, share options, or LTIP shares (Conyon \& Murphy, 2000, p.654). The link between CEO and shareholder wealth is further strengthened by a CEOs holding of unexercised shares, as the value of options held increase with the company's share price. The CEOs interest then becomes related to firm performance and stock price (Conyon \& Murphy, 2000, p.656). Hartzell and Starks (2003) found that a CEO's increased institutional ownership leads to increased pay-performance sensitivity.

In the UK, it was found that the value shares held by a CEO declines with company size, while the opposite effect is seen in the U.S.; that of an increase in share value with an increase in company size. Conyon and Murphy (2000) found hat on average, U.S. CEOs hold share worth $£ 145$ million, while UK CEOs hold shares worth $£ 3.4$ million. This trend continues till today, Fernandes, Ferreira, Matos, and Murphy (2012) found, when comparing firms of 14 countries, including Germany and UK, that institutional ownership by executives of U.S. firms is significantly higher than ownership of executives of non-U.S. firms. The study also found CEO pay to be positively related to institutional ownership. In specific, a $10 \%$ increase in institutional holdings led to a $4 \%$ increase in executive pay. The same could be said for equity-based compensation, which increased with an increase in institutional holdings (Fernandes et al., 2012, p.335). A CEO's institutional ownership had a positive effect on both CEO performance and compensation.

\section{Stock Options}

Perhaps the largest difference between the pay structure of CEOs of U.S. firms and CEOs of non-U.S. firms is stock option compensation. The international pay gap of CEOs widened significantly after accounting for gains from exercising share options. In 1997, the top 500 U.S. CEOs made $£ 2$ billion from option exercises; by contrast, the top 500 UK CEOs made only £74 million in exercised options (Conyon \& Murphy, 2000, p.640). These $£ 2$ billion in exercised options are an explanation for the drastic disparity in U.S. CEO Compensation as compared with their foreign counterparts. Stock ownership was higher in the U.S. when compare to the UK, as U.S. CEOs controls $0.29 \%$ of their companies stock and held options purchase $1.18 \%$ of their company. While UK CEOs owned $0.5 \%$ of their company's stock and held options to purchase a low $0.24 \%$ of their company when compared to U.S. CEOs (Murphy, p.4 \& 8). Stock options have become a more prevalent part of CEO compensation throughout the years. In the 1990s, German firms have more so begun granting stock options as compensation. By 1998, 10\% of German firms listed on the DAX offered options as part of CEO packages (Elston \& Goldberg, 2001, p.3).

Looking at large U.S. firms, in the early 1990 s, $82 \%$ offered executives options plans; this percentage quickly rose to $97 \%$ by 1997 . The opposite was found in the UK, with CEOs being compensated with less exercisable stock. The almost 100\% of firms offering option plans to executives in 1986 declined to 68\% by 1997 (Murphy, p.6-7).

The rise and fall of stock options can be explained by economic, political, and cultural factors in both the U.S. and the UK; however, with opposing effects. Stock options in the UK became controversial in 1995 when one CEO exercised options worth millions of pounds; LTIP performance share plans came to replace stock options. Whereas, in the U.S., stock options were perceived to be a better form of CEO compensation. Shareholders and academics believed that an increased inclusion of stock options into CEO pay packages would give executives more rewards and penalties, motivating them to work towards firm value. (Conyon \& Murphy, 2000, p.666). With the rapid increase in stock options as compensation in the 1990s, CEO compensation underwent structural changes in its adaptation to new regulations. However, despite granting CEOs massive grants, no other form of pay was reduced. The median CEO pay of S\&P 500 firms reached its peak in the year 2000, as seen in Table1, eventually declining during the 2008-2009 Great Recession and in the years after (Murphy, 2012, p.1). In a ten-year comparison, stock options accounted for $53 \%$ of total executive compensation of S\&P 500 firms in 2001, and only $21 \%$ in 2011 . While 
the use of stock grants increased, from $8 \%$ of compensation in 2001 to $36 \%$ in 2011 . The shift from stock options to restricted stock can be explained largely by governmental regulations that were enacted in response to corporate accounting scandals in the early 2000s (Kuehn, 2013, p.16).

Table 1. Obtained from Posner, Richard A., 2009, Are American CEOs Overpaid, And, If So, What if Anything Should Be Done About It? Duke Law Journal 58, 1013-1047.

\begin{tabular}{|llllrll|}
\hline Year & $\begin{array}{l}\text { Average } \\
\text { Compensation } \\
\text { (\$ millions) }\end{array}$ & $\begin{array}{l}\text { CEO } \\
\text { Average } \\
\text { Options } \\
\text { (\$ millions) }\end{array}$ & $\begin{array}{r}\text { Value } \\
\text { Granted }\end{array}$ & $\begin{array}{l}\text { Options as Percentage } \\
\text { of } \\
\text { Compensation }\end{array}$ & $\begin{array}{l}\text { Number } \\
\text { Observations }\end{array}$ \\
$\mathbf{1 9 9 2}$ & 2.329 & 0.706 & $30 \%$ & 363 \\
$\mathbf{1 9 9 4}$ & 2.151 & 0.872 & $41 \%$ & 1541 \\
$\mathbf{1 9 9 6}$ & 3.146 & 1.475 & $47 \%$ & 1642 \\
$\mathbf{1 9 9 8}$ & 4.495 & 2.258 & $50 \%$ & 1724 \\
$\mathbf{2 0 0 0}$ & 6.695 & 4.455 & $67 \%$ & 1782 \\
$\mathbf{2 0 0 2}$ & 4.909 & 2.576 & $52 \%$ & 1657 \\
$\mathbf{2 0 0 4}$ & 5.205 & 2.059 & $40 \%$ & 1675 \\
$\mathbf{2 0 0 5}$ & 5.472 & 1.860 & $34 \%$ & 1638 \\
\hline
\end{tabular}

The staggering difference can be explained by the weight of importance placed on stock price in different countries. Abbegglen and Stalk (1985) found that management teams of U.S. firms place considerable importance on stock market performance. In a survey they conducted, stock price was ranked as the second most important goal (out of nine objectives) for U.S. executives. While Japanese executives ranked stock price the least important objective (Murphy, p.12), focusing more so on firm value. Kubo (2001) found that there was no relationship between Japanese executives pay and the company's stock market performance, creating a friction between executive and shareholder interest. Needless to say, U.S. CEOs focus more so on increasing stock price because of its affect on a large percentage of their compensation.

\subsection{Risk in Compensation}

In receiving more compensation in the form of options than any other country, U.S. CEOs become the most heavily invested in their firms and experience the most risk. Receiving a large percentage of compensation as stock options creates a problem for risk-averse CEOs. By having to accept risky pay packages and undiversified portfolios, they will require a risk premium. This premium has various components and complications that can be measured at different weights; such as a CEOs risk aversion and diversification (Murphy, 2012, p.6), which is different for each individual CEO. Nevertheless, no matter how the premium is analyzed, it can explain, in part, the increased compensation of U.S. executives (Fernandes et al., 2012, p.339). This increased risk, however, can work to mitigate agency problems. The greater compensation CEOs receive as options, the more inclined they will be to increase firm value; as the value of unexercised options will increase or decrease depending on an increase or decrease in company stock price (Murphy, p.8).

Regardless of a CEO's stock ownership in the firm, their interest may still not align with that of company shareholders. CEOs are individual investors who will steer the firm in whatever direction they wish to take. A CEO may be more risk-tolerant than the firm's shareholders and take chances they would otherwise not. Unlike UK CEOs, who receive incentive based stock options and objective-oriented LTIP contingent upon performance; U.S. CEOs options are exercisable without restriction (Murphy, p.3). CEOs of U.S. firms are then, not motivated to reach specific performance objectives when receiving stock options or other share plans.

The UK's option programs have actually decreased in the 1990s due to the increase in disclosure requirements regarding CEO pay packages. A lack of restriction, and the desire for limitless gain and a loss equal only to the value of the option, make stock option a troubling form of executive compensation for shareholders. Sometimes executives will experience no loss from undertaking excessive risk. Options can be "re-priced" when the stock price falls below the original exercise price, at which point CEOs can exercise the option at a profit (Posner, 2009, p.1027). Stock options, then, loosen the ties between executive and shareholder interests. As executives motivation becomes their personal investment objectives rather than maximizing firm profit. 


\section{Company Size}

\subsection{Sales Revenue \& Profit}

Unfortunately for shareholders, firm profitability is not a major concern for CEOs in relation to their compensation. Compensation was found to mostly correlate with the growth and size of a firm, and the scale of its operations (Murphy, p.1). Executive compensation increases with an increase in the firm's size, giving CEOs incentives to set goals to increase company size, objectives which may not align with shareholder interests. This can be seen in both German and U.S. firms (Elston \& Goldberg, 2001, p.6). Sales and ROE were found to positively correlate with compensation of CEOs of German firms (Elston \& Goldberg, 2001, p.4). CEO pay can more closely related to company profits by compensating CEOs based on short-run accounting profits. Giving executives incentives to increase short-run profits in the least (Murphy, 2012, p.37-38).

Trends in the value of profit to a CEO differ between countries. In a study of 45 large U.S. industrial firms, conducted between 1953-1959, McGuire, Chiu, and Ebling (1962) found that a correlation exists between sales and executive income, while a significant relationship lacks between profit and executive income. Tosi, Werner, Katz, and Gomez-Mejia (2000) found that firm size accounts for $40 \%$ of total CEO pay, while firm performance accounts for only $5 \%$ of total pay. However, changes in both have similar pay sensitivity, with $5 \%$ explained by change in size and $4 \%$ explained by change in financial performance. The same could be said for Japanese firms. Kubo (2001) found the relationship between CEO compensation and company profitability to be weak. Kubo could not reach a conclusive decision regarding firm profitability and executive compensation in the UK. In recent years, Buigit, Soi, Koskei (2014) found that profitability positively impacts compensation of UK executives. It becomes crucial to link CEO compensation to corporate and individual performance (Buigit et al., 2014, p.223). Giving CEOs greater incentive to work towards increasing firm profitability.

With a lack of motivation for CEOs to increase firm profit and a more fixed focus on increasing sales, the pressure of minimum profit constraints placed on a CEO could shift their focus. Bamuol suggested that executives should need to set profit goals that at least satisfy shareholders expectations and provide enough funds for future growth (McGuire et al., 1962, p.1). Linking reward more closely to performance, as done with UK firms, can be an effective method to shift CEO focus on profit generating objectives.

\subsection{Number of Employees in a Firm}

The growth of a company and its number of employees can have an effect on an executive's compensation. Galbraith (1988) explains that the larger the size of a firm, the more employees would need to be hired, hence increasing an executive's responsibility and increasing compensation accordingly. In relating compensation to company size, the gap between U.S. and other foreign firms can be partially explained. For example, the average U.S. firm is larger than the average UK firm. The management of U.S. firms, then, becomes more complicated, and executives would be more greatly compensated. With larger firms, competition when hiring mangers becomes more intense, it is argued that this will raise the level of CEO compensation (Posner, 2009, p.1030). This trend has been consistent throughout the years, as Ciscel (1974) found the number of employees in a firm, or the size of a firm's techno-structure, and executive compensation to be highly correlated.

Since 1980, the compensation of American CEOs has been found to increase with an increase in their firm's market value. In comparing U.S. CEOs to Japanese CEOs in regard to firm growth, Jensen and Murphy (1990) found U.S. CEOs have more incentive to increase shareholder wealth. Close monitoring of Japanese's executives by banks and shareholders causes disincentives to maximize shareholder wealth (Murphy, p.16). U.S. executives will receive greater pay in putting a greater effort to increase shareholder wealth and firm growth than Japanese executives would.

\section{Bonus Plans}

Unlike stock options or other forms of compensation, bonuses are awarded to executives based on specific performances. Bonuses received as compensation, motivate CEOs to put in the work and focus on taking steps most beneficial for the firm. A CEO may receive a much lower bonus than he/she anticipates if they do not achieve profit-maximizing goals.

This is called a "grant-date value," in which bonus plans are given only when earned (Murphy, 2012, p.8). Cash bonus payments in Germany are directly related to a firm's stock market and financial performance (Heimes and Seemann, 2011, pe.3). Because German executives receive bonuses only after achieving account-based objectives, their wealth becomes indirectly related to that of shareholder wealth's (Conyon \& Murphy, 2000, p.654); giving them incentives to work towards shareholder interest. 
Bonuses account for a large portion of total compensation in the U.S., but even more so in Germany. From sample of 393 CEOs, in 2005, Heimes and Seemann (2011) found that $42 \%$ of total compensation was received as bonuses and rose to almost half of pay by 2007. This percentage, however, keeps fluctuating. Almost $80 \%$ of executives of German firm's use short-run performance to determine bonuses. In 2009, Heimes and Seemann (2011) showed that bonuses decreased to $36 \%$ of total pay. Murphy found UK and U.S. executives to have bonuses around the same percentage of total CEO compensation, $18 \%$ and $17 \%$ respectively. However, the median U.S. bonus tripled that of UK executives. U.S. bonuses became a slightly larger percentage of total executive pay than UK bonuses by 2006, after controlling for sales, industry, firm, ownership, and board characteristics (Fernandes et al., 2012, p.337), as shown below in Figure 2.

\section{$\square$ Equity-based Pay $\quad \square$ Bonuses $\quad \square$ Other $\quad \square$ Salary}

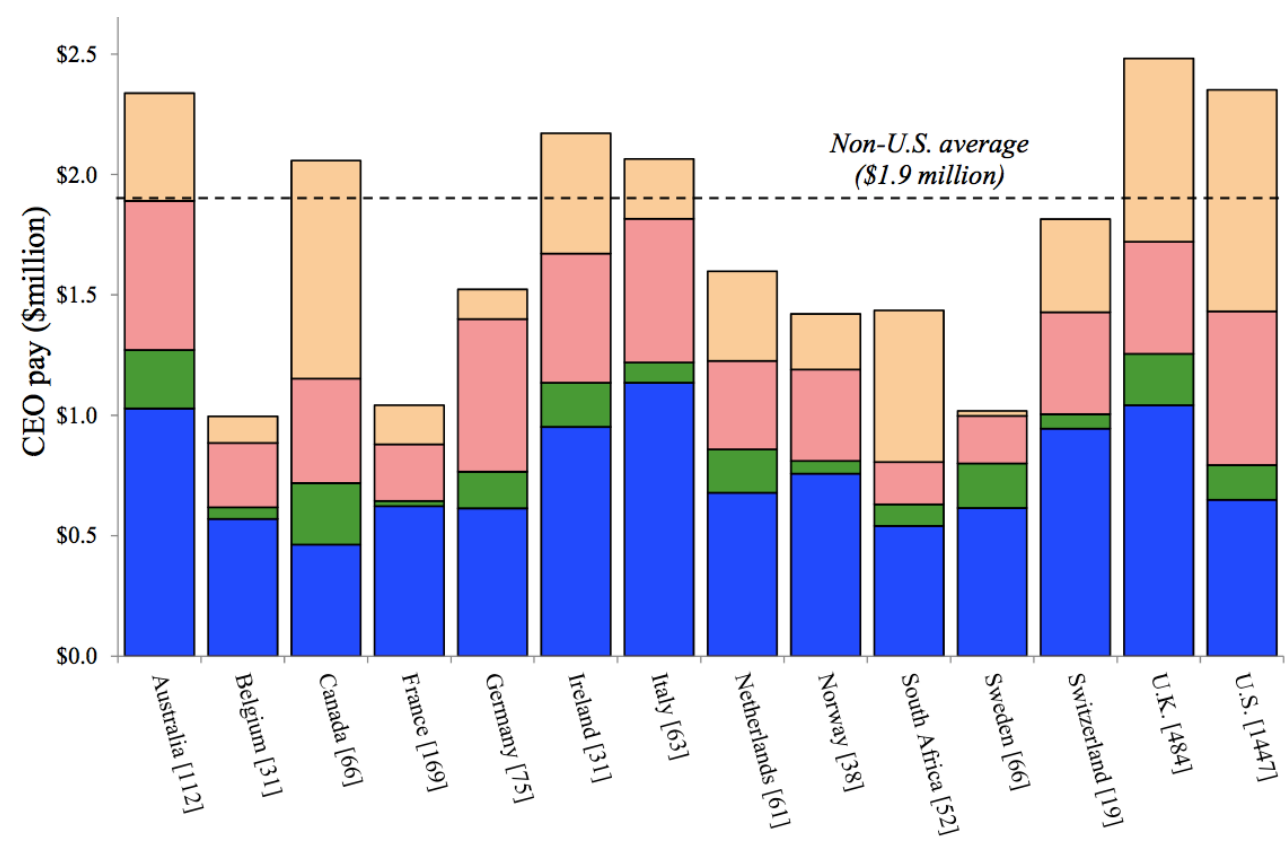

Figure 2. Predicted level and structure of 2006 CEO pay for firms with $\$ 1$ billion in revenues.

Obtained from Fernandes, Nuno, Ferreira, Miguel A., Matos, Pedro, and Murphy, Kevin J., 2012, Are U.S. CEOs

Paid More? New International Evidence. Oxford University Press 26, 323-367.

Even though bonus plans are based on performance, they still do not ensure a CEOs focus on increasing firm value. Bonuses are paid to CEOs after reaching a lower performance threshold or hurdle, at which point "hurdle bonus" is received. After reaching that threshold, the bonus is capped at an upper limit performance and does not increase based on an executives increased performance (Conyon \& Murphy, 2000, p.33-34). After a CEO reaches their target bonus, bonus plans do not motivate them to continually improve their performance or firm value. The problem that arises that bonus plans are not measured simply on an executive's performance, rather their performance relative to a benchmark.

Such benchmarks may include, EPS relative to last years EPS, measured net income relative to budgeted net income, or measuring performance relative to financial or nonfinancial strategies (Murphy, 2012, p.36).

Many problems arise when bonus plans are structured around benchmarks. If the benchmark is based on last year's performance, executives will not perform to the best of their ability in one year, so as to not be penalized for it in the bonus plan in the next year (Murphy, 2012, p.37). Lazear (1989) and Gibbons and Murphy (1990) found that when benchmarks are determined based on performance compared to ones colleges, issues of sabotaging co-executives to increase one's own bonus arise. Dye (1992), explains that setting benchmarks based on industry peers can also deter high performance. Executives may choose to enter a weak or defective industry so as to set low performance standards.

Executives can also manipulate the benchmark if it is set based on meeting a budget. Budget-based incentives can lead a CEO to set a low budget and increase their performance by contrast (Murphy, 2012, p.37). Benchmarks 
become especially problematic when a company uses external benchmarks. Explained by Murphy (2000) as "benchmarks based on fixed numbers or schedules, industry performance, or the cost of capital." Firm's that used such factors as benchmarks, rather than internal benchmarks, experienced difficult financial performances by the end of their fiscal year.

\section{Conclusions}

The reasons for the pay gap can still be explained through the larger size of an average U.S. firm, when compared to an average British firm, for example. U.S. CEOs are viewed to be more capable and productive than their foreign counterparts and are awarded accordingly.

Stock options received as compensation account for a major difference in the structure of executive pay packages between U.S. and non-U.S. firms. U.S. executives also do not need to rely on performance or objective-oriented compensation. They can exercise stock options, LTIP, and other share plans without goal specific restrictions.

The international pay gap between U.S. and non-U.S. CEOs has not completely disappeared. However, it has been diminishing in the recent years, and is expected to continue shrinking with the increase of internationalization and Americanization of non-U.S. firms. Fernandes, Ferreira, Matos, and Murphy (2012) find that the level and structure of CEO compensation in the U.S. has become similar to that of their foreign counterparts. Mainly, the U.S. pay premium has been found to be economically modest, after controlling for board and firm characteristics; and has reduced after adjustment for risk. Another defining factor is the fact that non-U.S. firms have been increasingly adopting U.S. pay practices, in terms of equity-based compensation in specific. With the increased similarity in U.S. and non-U.S. pay packages, the international pay gap is not the atrocity it used to be just a few years ago.

\section{References}

Abegglen, J., \& Stalk Jr., G. (1985). Kaisha: The Japanese Corporation. Basic Books, New York.

Ackman, D. (2002). Pay Madness at Enron 03.22.2002 Business Week.

Ackerman, D. (2007). "Letter from Washington: As U.S. rich-poor gap grows, so does public outcry". Bloomberg News. International Herald Tribune. Retrieved 2007-02-18.

Ang, James S., Gregory L. Nagel, \& Jun Yang. (2010). The Effect of Social Pressures on CEO Compensation, Working Paper, Florida State University.

Bakija, Jon, Adam Cole, Bradley T. Heim. (March 2012). Jobs and Income Growth of Top Earners and the Causes of Changing Income Inequality: Evidence from U.S. Tax Return Data

Bebchuk, Lucian; Grinstein, Yaniv. (April 2005). "The Growth of Executive Pay". Harvard University: John M. Olin Center for Law, Economics and Business.

Bebchuk \& Fried. (2004). Pay Without Performance.

Bebchuck, Lucian A., \& Stole, Lars A. (1993). Do Short-Term Objectives Lead to Under- or Overinvestment in Long-Term Projects? The Journal of Finance 48, 719-729.

Bogle, J.C. (2008). Reflections on CEO Compensation. Academy of Management, May 2008. http://dx.doi.org/10.5465/amp.2008.32739756

Buigit, Kibet K., Soi, Neddy C., \& Koskei, Irene J. (2014). Determinants of CEO Compensation Evidence from UK Public Limited Companies. International Journal of Business and Management 10, 223-230. http://dx.doi.org/10.5539/ijbm.v10n1p223

Carpenter, Jennifer \& David Yermack. (1999). Executive Compensation and Shareholder Value: Theory and Evidence, ed. (Boston: Kluwer Academic Publishers.

Chemi, E., \& Giorgi, A. (2014). The Pay-for-Performance Myth., Business Week, July 22, 2014.

Chhaochharia, Vidhi, \& Grinstein, Yaniv. (2009). CEO Compensation and Board Structure. Journal of Finance, 64, 231-261. http://dx.doi.org/10.1111/j.1540-6261.2008.01433.x

Ciscel, David H. (1974). Determinants of Executive Compensation. Southern Economic Journal 40, 613-617. http://dx.doi.org/10.2307/1056379

Conyon, Martin J., \& Kevin J. Murphy. (2000). The Prince and the Pauper? CEO Pay in the United States and United Kingdom, Economic Journal 110, F640-F671. http://dx.doi.org/10.1111/1468-0297.00577

Conyon, Martin J., Fernandes, Nuno, Ferreira, Miguel A., Matos, Pedro, \& Murphy, Kevin J. (2011). The Executive 
Compensation Controversy: A Transatlantic Analysis. (ICS 2011-002) Retrieved from Cornell University, ILR School, Institute for Compensation Studies site.

Dye, Ronald A. (1992). Relative Performance Evaluation and Project Selection, Journal of Accounting Research 30, 27-52. http://dx.doi.org/10.2307/2491090

Ellig, B. (2002). The complete guide to executive compensation, 2002.

Elston, Julie A., \& Goldberg, Lawrence G. (2001). Executive Compensation and agency Costs in Germany. Working Paper, Oregon State University.

Equilar. (2011). CEO Pay Strategies Report for S\&P 500 Companies.

Fernandes, Nuno, Ferreira, Miguel A., Matos, Pedro, \& Murphy, Kevin J. (2012). Are U.S. CEOs Paid More? New International Evidence. Oxford University Press 26, 323-367.

Galbraith, John K. (1988). Time and the New Industrial State. The American Economic Review 78.

Gerakos, Joseph J., Piotroski, Joseph D., \& Srinivasan, Suraj. (2011). Do US Market Interactions Affect CEO Pay? Evidence from UK Companies. Harvard Business School, Working Paper 11-075, 1-53. http://dx.doi.org/10.2139/ssrn.1738083

Gibbons, Robert, \& Kevin J. Murphy. (1990). Relative Performance Evaluation for Chief Executive Officers, Industrial and Labor Relations Review 43, 30S-51S. http://dx.doi.org/10.1177/001979399004300303

Heimes, Moritz, \& Seemann, Steffen. (2011). Compensation and Incentives in German Corporations. University of Konstanz - Department of Economics, Working Paper Series 2011-20.

Jensen, Michael C., \& Murphy, Kevin J. (1990). Performance Pay \& Top Management Incentives. Journal of Political Economy 98. http://dx.doi.org/10.1086/261677

Kubo, Katsuyuki. (2001). The Determinants of Executive Compensation in Japan and the UK: Agency Hypothesis or Joint Determination hypothesis? Hitotsubashi University - Institue for Economic Research, CEI Working Paper Series.

Kuehn, Christopher. (2013). Unintended Consequences? The Effects of Regulation on Executive Compensation: Evidence from the Forbes 500. Wesleyan University - Departmental Honors in Mathematical Economics, Thesis (Essay).

Lazear, Edward P. (1989). Pay Equality and Industrial Politics, Journal of Political Economy 97, 561-580. http://dx.doi.org/10.1086/261616

McGuire, Joseph W., Chiu, John S. Y., \& Elbing, Alvar O. (1962). Executive Incomes, Sales and Profits. The American Economic Review 52, 753-761.

Morgenstern, G. (June 29, 2013). "An Unstoppable Climb in C.E.O. Pay". New York Times. Retrieved 28 August 2013.

Murphy, Kevin J. (2000). Performance Standards in Incentive Contracts, Journal of Accounting \& Economics 30, 245-278. http://dx.doi.org/10.1016/S0165-4101(01)00013-1

Murphy, Kevin J. (2012). Executive Compensation: Where We Are, and How We Got There. Handbook of the Economics of Finance No. FBE 07.12, 1-175. http://dx.doi.org/10.2139/ssrn.2041679

Oxelheim, Lars, \& Randoy, Trond. (2004). The Effects of Internationalization on CEO Compensation. The Research Institute of Industrial Economics, Working Paper No. 611. http://dx.doi.org/10.2139/ssrn.546504

Payscale.com. (2011). The Basics of Executive Compensation, 28 February 2011.

Posner, Richard A. (2009). Are American CEOs Overpaid, And, If So, What if Anything Should Be Done About It? Duke Law Journal 58, 1013-1047.

Schmidt, Cornelius. (2012). Does Transparency Increase Executive Compensation? Working Paper, University of Lausanne \& Swiss Finance Institute 2013.

Tosi, Henry L., Werner, Steve, Katz, Jeffery P., \& Gomez, Luis R. (2000). How Much Does Performance Matter? A Meta-Analysis of CEO Pay Studies. Journal of Management 26, 301-339. http://dx.doi.org/10.1177/014920630002600207

Zajac, Edward J., \& Westphal, James D. (1995). Accounting for the Explanations of CEO Compensation: Substance and Symbolism. Administrative Science Quarterly 40, 283-308. http://dx.doi.org/10.2307/2393639 